\title{
Analytical Validation of LAL Kinetic Assay for Detection and Quantification of Endotoxins in Measles's Vaccine Diluents
}

\author{
Rosane Cuber Guimarães and Alaide Aline Xavier Leal ${ }^{*}$ \\ Setor de Validação Analítica; Laboratório de Metrologia e Validação; Departamento da Garantia da Qualidade; \\ Bio-Manguinhos; FIOCRUZ; Rio de Janeiro - RJ - Brasil
}

\begin{abstract}
Method validation is the process used to confirm that the analytical procedures employed for a specific test is able to produce reliable and replicable results. An analytical method should be conducted in order to demonstrate that it is suitable for its intended use [1]. The aim of this present work is to demonstrate and evaluate the suitability of method validation. The analytical validation discussed herein was conducted by prescribed protocol, using 3 different batches of measles's vaccine diluents. All of the stipulated validation parameters: linearity, repeatability, reproducibility (intermediate precision) and accuracy were met. Additionally, this study demonstrated the method's capability for the determining endotoxin levels in measles's vaccine diluents and its further use in apirogenic water samples.
\end{abstract}

Key words: Bioanalytical method, endotoxin, validation

\section{INTRODUCTION}

The Lymulus amebocyte lysate (LAL) kinetic assay is a test that is used to detect and quantify gram negative bacteria endotoxins (aka: lipopolysaccharides [LPS], or endogenous pyrogens) that may be present in biotechnological products. Once bacterial endotoxin is determined to be a contaminant, its levels must be measured, as this dramatically affects the results.

A sample is mixed with the LAL/substrate reagent, placed in an incubating plate reader, and monitored over time for the appearance of a turbidity (identified by a yellowish color). This may occur quite quickly if there are high levels of endotoxin present in it.
The time required to attain a turbid state is referred to as the Reaction Time and is inversely proportional to the amount of endotoxin present, and thus the concentration of endotoxin in unknown samples can be calculated from a standard curve.

The present method, described in the United States Pharmacopeia - USP[2], was validated according to parameters set by the U.S. Food and Drug Administration - FDA [3] plus precision parameters cited in the Guia para Qualidade em Química Analítica - ANVISA [4].

\footnotetext{
* Author for correspondence
} 


\section{METHODS}

The LAL kinetic assay is performed in a 96 well plate with predetermined conditions of reaction temperature $\left(37^{\circ} \mathrm{C} \pm 1^{\circ} \mathrm{C}\right)$, final volume $(200 \mu \mathrm{L})$ and sample $\mathrm{pH}(6-8)$.

The validation parameters were the following:

- The linearity of an analytical method is its ability to elicit test results that are directly,

or by means of well-defined mathematical transformations, proportional to the concentration of analytes in samples within a given range. For this study, linearity was determined by constructing a calibration curve that compares reaction time versus concentration, using $50 \mathrm{EU} / \mathrm{mL}$ of a control standard endotoxin (CSE).

The analysis was carried through 3 times for each dilution in a range of concentration of $5 \mathrm{x}$ $10^{-3}$ to $0,5 \mathrm{EU} / \mathrm{mL}$ in triplicate. The results were used to produce a linear regression curve for the determination of linear (b) and angular (a) parameters. . Additionally the correlation coefficient (r) and replicates relative standard deviation (RSD\%) were also determined.

- Precision ( Repeatability, and Intralaboratorial Reproducibility )

- Repeatability: Three different batches of Measles's vaccine diluents (apirogenic water) were used and three repetitions were carried out by the same analyst, using a single piece of equipment over a relatively short time span. An assay was also conducted using one batch of Measles's vaccine diluents spiked with a CSE concentration of $0,05 \mathrm{EU}$ in a 1:1 dilution. Ten repetitions were performed with the same assay conditions and, by the same analyst in a single day and using the same equipment.

- Intralaboratorial Reproducibility (Intermediate precision): was carried out using an individual batch of vaccine diluents. This lot was spiked with a CSE concentration of $0,05 \mathrm{EU}$ in a 1:1 dilution and performed with triplicates of each sample by three different analysts on different days. The reported values were: individually results; mean; standard deviation and relative standard deviation.

- The accuracy of an analytical method is the extent to which test results generated by the method and the true value agree. The extent of agreement is measured using confidence intervals. For impurity quantification, the accuracy is determined by sample analyses spiked with a known concentration of the given impurity. For this parameter three different batches of Measles's vaccine diluents (apirogenic water) were used, spiked with a CSE concentration of $0,05 \mathrm{EU}$ in a 1:1 dilution. Three repetitions were performed with the same assay conditions, by the same analyst in a single day and using the same equipment. The reported values were: Individual results; mean; relative standard deviation and recovery.

\section{RESULTS}

Table 1 below shows the LAL kinetic assay obtained values for detection and quantification of endotoxins in measles's vaccine diluents. The method validation parameters of linearity, precision and accuracy meet the established acceptance criteria $[2,3]$.

Table 1 - Method validation results.

\begin{tabular}{lrr}
\hline Parameters for method validation & Results & Acceptance criteria \\
\hline & $\mathrm{r}=-0,9997$ & $\mathrm{r}=-1 \mathrm{a}-0,98$ \\
Linearity & $\mathrm{R}^{2}=0,9995$ & $\mathrm{R}^{2}>0,99$ \\
& $(\mathrm{a})=-0,2830$ & $(\mathrm{a})=-0,3 \mathrm{a}-0,1$ \\
Repeatability & $(\mathrm{b})=+2,931$ & $(\mathrm{~b})=+2,5 \mathrm{a}+3,5$ \\
Intralaboratorial Reproducibility & $\mathrm{RSD}_{\mathrm{r}}=1,48 \%$ & $\mathrm{RSD}_{\mathrm{r}}<2 \%$ \\
Accuracy(Recovery) & $\mathrm{RSD}_{\mathrm{R}}=1,39 \%$ & $\mathrm{RSD}_{\mathrm{R}}<4 \%$ \\
& $83 \%$ & $50 \% \mathrm{a} 150 \%$ \\
\hline
\end{tabular}

Beyond the verification of the parameters above, the FDA as well as the USP only consider a capable laboratory for LAL assay if all of its technicians are capable of producing valid standard curves (log of endotoxin concentration in $\mathrm{EU} / \mathrm{mL}$ against $\log$ of reaction time) using 
linearity criteria. The degree of product inhibition or enhancement of the LAL procedures should be determined for each drug formulation before the LAL test is used to assess the endotoxin content of any drug.

All three technicians' Standard curves involved in this method validation are demonstrated in figures 1, 2 and 3. Table 2 demonstrates, as USP and FDA suggest, the lack of interference factors in the assayed samples.

The amount of endotoxin to be added in the sample is calculated establishing the "Pass/Fail Cutoff" - PFC value in accordance with the formula:

$$
\begin{aligned}
& \mathrm{PFC}=\text { Endotoxin limit } \\
& \mathrm{MVD}
\end{aligned}
$$

where:

MVD $=\underline{\text { Endotoxin limit }}$ $\lambda$

MVD $=$ Maximum valid dilution $\lambda=$ lower endotoxin concentration in standard curve

If $\mathrm{PFC}<1,0 \mathrm{EU} / \mathrm{mL}-$ Spike concentration $=0,1 \mathrm{a}$ $0,5 \mathrm{EU} / \mathrm{mL}$.

If $\mathrm{PFC}>1,0 \mathrm{EU} / \mathrm{mL}-$ Spike concentration $=1,0 \mathrm{a}$ $5,0 \mathrm{EU} / \mathrm{mL}$.

The results of $\mathrm{C}$ series in table 2 must meet the validation requirements described in linearity parameter. For this validation we looked at both the linearity and USP criteria, plotting data along a standard curve in accordance with what is prescribed in linearity methods. We expected endotoxin recovery rates between 50 and $150 \%$ after the solution " $\mathrm{B}$ "concentration was subtracted from the solution " $A$ " concentration. Our validation proved to be extremely accurate. The result of negative control $\mathrm{D}$ series was not expected to exceed the endotoxin limits dictated by the curve $(\lambda)$. Apirogenic water was used for negative control during all tests, resulting in endotoxin amounts below of $5 \times 10^{-3} \mathrm{EU} / \mathrm{mL}$.

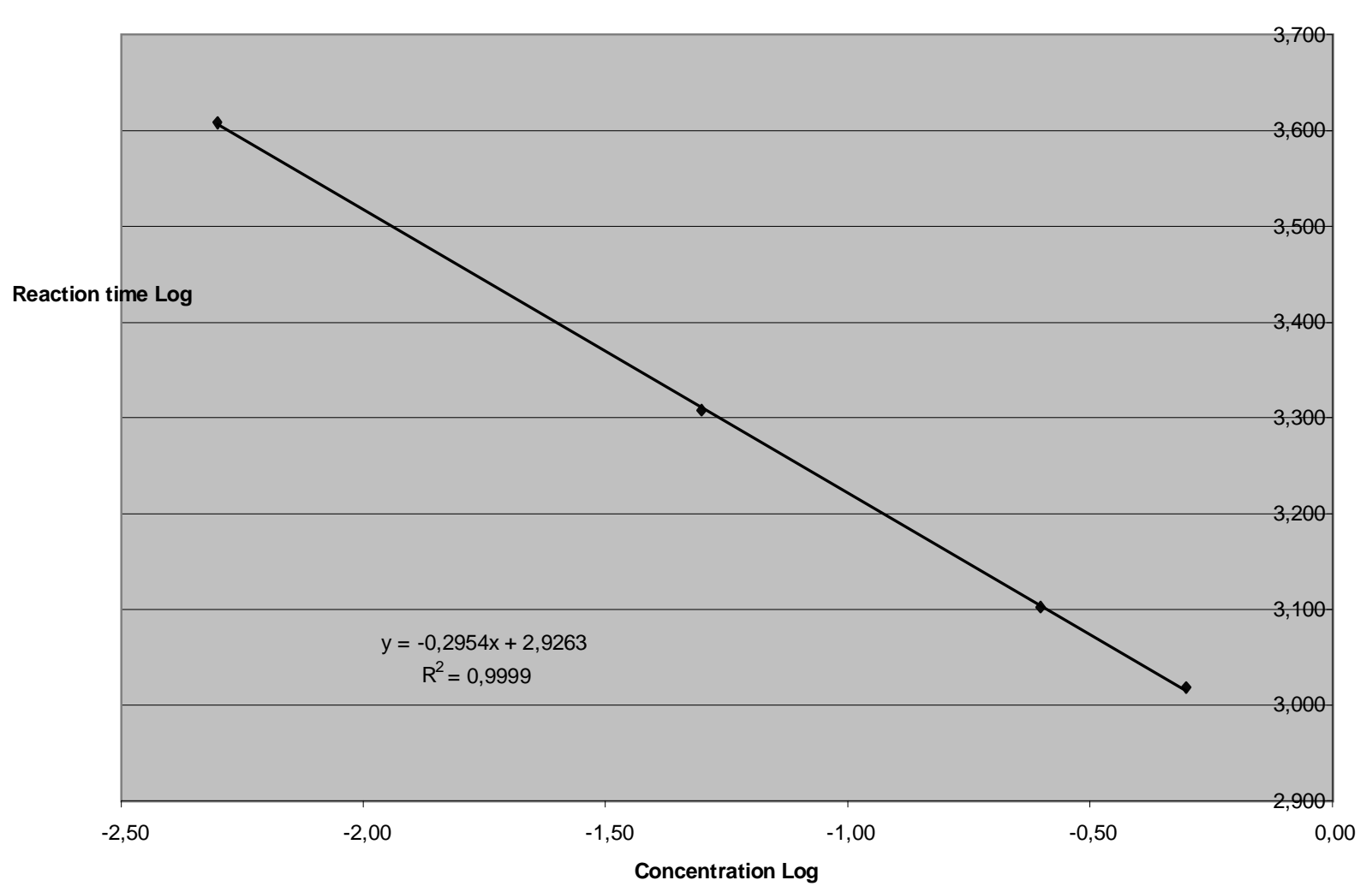

Figure 1 - Standard curve analyst 1 


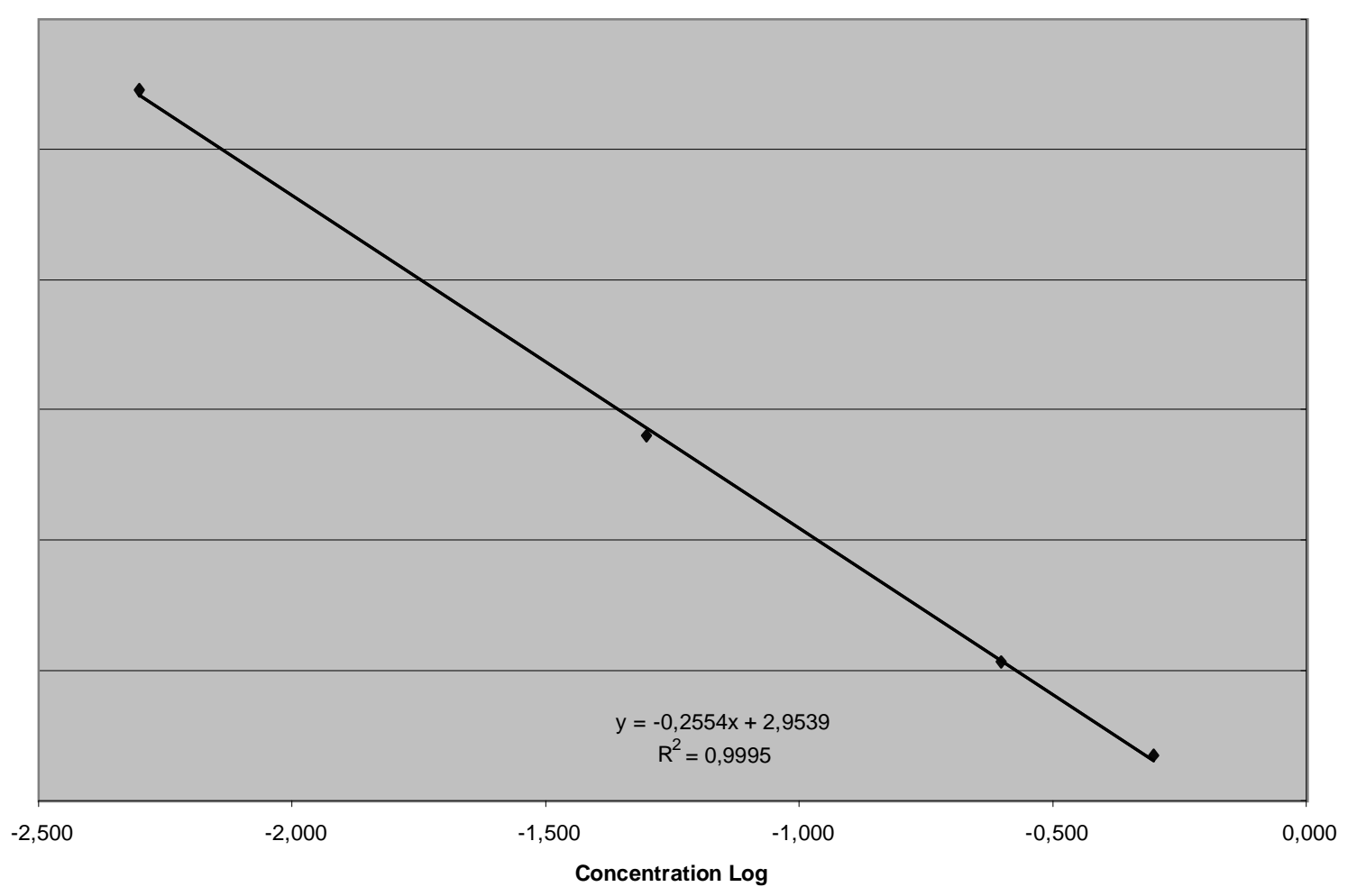

Figure 2 - Standard curve analyst 2

\section{DISCUSSION}

According to the "Guia para validação de métodos analíticos e bioanalíticos" - RE n n $^{899}$, of May 292003 published by Agência Nacional de Vigilância Sanitária - ANVISA, analytic methods described in official pharmacopeias or national formularies will be recognized by ANVISA and considered valid [5]. However, both the FDA [1], and USP [2] publications require that laboratories demonstrate the qualifications of each technician and verify the absence of interfering factors.

This is due to the numerous sources of variation encountered in laboratories processes, equipment, diluents and glassware. As such, it becomes imperative that laboratories with quality controls in place confirm the validation parameters before routinely analyzing their samples [6].

In this validation study, not only the equipment Microplates Reader, but also the software were calibrated and qualified, and found to meet or exceed all standards.
All of the validation references cited in this work recommended that at least 3 different concentrations of samples are utilized in order to properly conduct the repeatability test. It was not possible to meet these recommendations for once the measles diluent's samples (apirogenic water) are processed without dilution, the results become too low to be read by the laboratory equipment.

This challenge was overcome by computing replicability after a concentration of $0,05 \mathrm{EU} / \mathrm{mL}$ standard endotoxin in a 1:1 dilution was added to the samples.

The fact that the samples of measles's vaccine diluents were of apirogenic water (WFI) allowed us to apply this validation not only to the diluent samples, but also to water itself, forgoing the need for another validation process. 


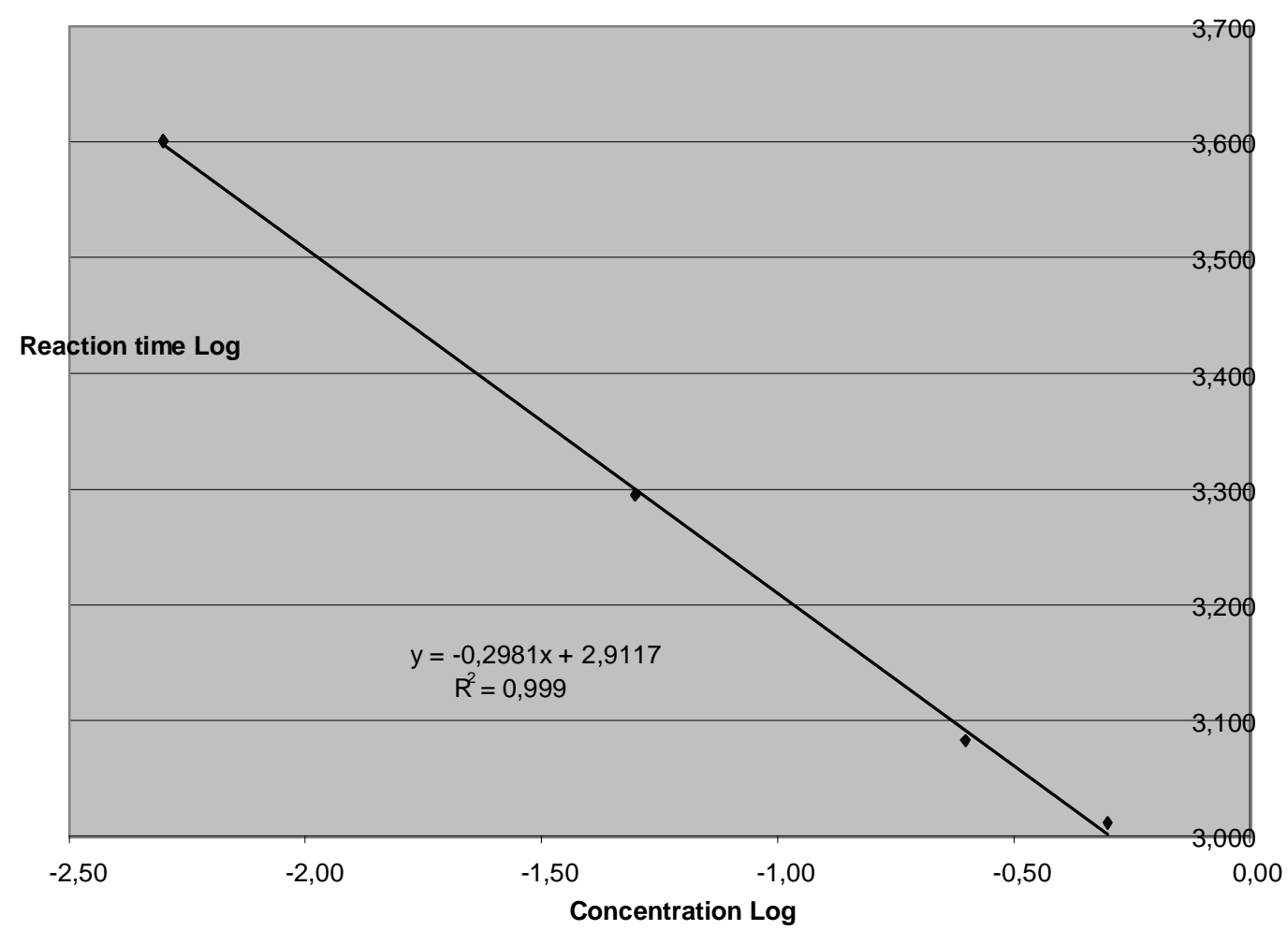

Figure 3 - Standard curve analyst 3

Table 2 - Preparation of Solutions for the Inhibition/Enhancement Test for Photometric Techniques

\begin{tabular}{|c|c|c|c|}
\hline Solution & Endotoxin Concentration & $\begin{array}{l}\text { Solution to which Endotoxin } \\
\text { is Added }\end{array}$ & Number of Replicates \\
\hline $\mathrm{A}^{\mathrm{a}}$ & None & Sample solution & 3 \\
\hline $\mathrm{B}^{\mathrm{b}}$ & $\begin{array}{r}\text { Middle concentration of the } \\
\text { standard curve }\end{array}$ & Sample solution & 3 \\
\hline $\mathrm{C}^{\mathrm{c}}$ & $\begin{array}{l}\text { At least } 3 \text { concentration (lowest } \\
\text { concentration is designated } \lambda \text { ) }\end{array}$ & Apirogenic water & Each not less than 3 \\
\hline$D^{d}$ & None & Apirogenic water & 3 \\
\hline
\end{tabular}

\section{CONCLUSION}

The analytical validation of LAL Kinetic Assay for the detection and quantification of endotoxins in measles's vaccine diluents (apirogenic water) was conducted per protocol using 3 batches of samples.
The concentration level (in EU/mL) between the least and the greatest value on the standard curve (range) was $2-\log$ with 4 points $(0,005 ; 0,05 ; 0,25$ and 0,5). The Onset OD was 0,100 and a regression analysis was conducted using linear regression as required by the FDA guidelines. All parameters of linearity were met. The average 
value of the coefficient of correlation of the standard curves was 0,9997 , the average values of the angular and linear coefficients were $-0,2830$ and $+2,931$ respectively. The validation proved to be both specific and accurate, once the spike recovery rates were between $50 \%$ and $150 \%$. All the replicates relative standard deviations remained below $4 \%$, meeting the requirements of precision and repeatability. This validation also served to demonstrate the qualifications of the technicians, as all of them were capable to produce valid standard curves.

As such, the present work shows that the analytical method is adequately playing its function, or in other words, it demonstrates that endotoxins controls are

specifically/selectively recovered without detectable

interferences in the test samples through linearity, accuracy and precision.

The calculation of uncertainty of this validated method is currently in progress.

\section{ACKNOWLEDGEMENTS}

The authors would like to thank the Laboratory of Microbiologic Control (LACOM) for having conducted the method validation tests.

\section{RESUMO}

Validar um método é o processo de demonstrar que a seqüência analítica adotada é capaz de produzir resultados confiáveis e reprodutíveis. Dessa forma, um método analítico deve ser submetido a estudos laboratoriais que demonstrem que o mesmo atenda às exigências requeridas pelo tipo de determinação a que se destina [1]. Assim o objetivo do presente trabalho foi demonstrar a validação do método e a avaliação quanto a sua adequação. Esta validação analítica foi realizada conforme descrito em protocolo, utilizando 3 lotes de diluente para vacina contra sarampo. Todos os parâmetros de validação estipulados: linearidade, repetibilidade, reprodutibilidade intralaboratorial e exatidão foram atendidos. Este estudo também demonstrou a adequação ao método para a determinação de endotoxina para diluente de vacina contra sarampo e sua extensão para amostras de água apirogênica.

\section{REFERENCES}

[1] Instituto Nacional de Metrologia, Normalização e Qualidade Industrial (2003), Orientações sobre validação de métodos de ensaios químicos DOQ-CGCRE-008.

[2] United States Pharmacopeia 24 and National Formulary 19 (2000), Supplement - <85> Bacterial Endotoxins Test. pp. 2875-2879.

[3] Food and Drug Administration (1987), Guideline on validation of the Limulus Amebocyte Lysate test as an end-product endotoxin test for human and animal parental drugs, biological products, and medical devices. U. S. Department of Health and Human Services.

[4] Agência Nacional de Vigilância Sanitária (2004), Guia para qualidade em química analítica: uma assistência a acreditação. v. 1.

[5] Agência Nacional de Vigilância Sanitária (2003), $R E$ n. 899: guia para validação de métodos analíticos e bioanalíticos.

[6] McCullough, K. Z. (1989), Variability in the LAL Test In: LAL Panel Discussion at the PDA Spring. New York. Meeting ... New York. 